\title{
Stability of Hydromorphone-Ketamine Solutions in Glass Bottles, Plastic Syringes, and IV Bags for Pediatric Use
}

\author{
Mary H H Ensom, Diane Decarie, Karen Leung, and Carolyne Montgomery
}

\begin{abstract}
Objectives: To evaluate the stability of mixtures of hydromorphone and ketamine in $0.9 \%$ sodium chloride (normal saline [NS]) after storage for up to 7 days at room temperature $\left(25^{\circ} \mathrm{C}\right)$.

Methods: The stability of 3 standard mixtures of hydromorphone and ketamine (hydromorphone $0.2 \mathrm{mg} / \mathrm{mL}+$ ketamine $0.2 \mathrm{mg} / \mathrm{mL}$, hydromorphone $0.2 \mathrm{mg} / \mathrm{mL}$ + ketamine $0.6 \mathrm{mg} / \mathrm{mL}$, and hydromorphone 0.2 $\mathrm{mg} / \mathrm{mL}+$ ketamine $1.0 \mathrm{mg} / \mathrm{mL}$ ) in NS was studied. Portions of each mixture were transferred to 3 brown glass bottles $(100 \mathrm{~mL}), 3$ plastic syringes $(50 \mathrm{~mL})$, and $3 \mathrm{IV}$ bags $(50 \mathrm{~mL})$, which were then stored at room temperature $\left(25^{\circ} \mathrm{C}\right)$. Physical characteristics, including $\mathrm{pH}$, colour, and precipitation, were evaluated daily. Three $1.5-\mathrm{mL}$ samples were collected from each bottle, syringe, and IV bag at baseline, at 24, 48, and 72 hours, and on day 7. Samples were analyzed in triplicate by a stability-indicating high-performance liquid chromatography method. Solutions were considered stable if they maintained $90 \%$ of the initial concentration of each drug. Samples from syringes and IV bags were subjected to standard sterility testing by incubation for 5 days in an enriched culture media.
\end{abstract}

Results: No notable changes in $\mathrm{pH}$ or colour were observed, and no precipitation occurred in any of the solutions. All formulations maintained more than $90 \%$ of the initial concentration of each drug on day 7. No bacterial growth was observed in any of the samples tested.

Conclusions: Mixtures of hydromorphone and ketamine were stable for up 7 days at $25^{\circ} \mathrm{C}$, and the sterility of the preparations was maintained. Because stability alone does not guarantee efficacy, it is recommended that clinical studies be conducted to evaluate the pharmacokinetics and pharmacodynamics of these formulations.

Key words: patient-controlled analgesia, pediatrics, stability, highperformance liquid chromatography, hydromorphone, ketamine, pain

Can J Hosp Pharm 2009;62(2):112-118

\section{RÉSUMÉ}

Objectifs : Évaluer la stabilité de mélanges d'hydromorphone et de kétamine dans du chlorure de sodium à $0,9 \%$ (solution physiologique salée) entreposés pendant une période allant jusqu’à sept jours à la température ambiante $\left(25^{\circ} \mathrm{C}\right)$.

Méthodes : La stabilité de trois mélanges standard d'hydromorphone et de kétamine (hydromorphone à $0,2 \mathrm{mg} / \mathrm{mL}+$ kétamine à $0,2 \mathrm{mg} / \mathrm{mL}$, hydromorphone à $0,2 \mathrm{mg} / \mathrm{mL}$ + kétamine à $0,6 \mathrm{mg} / \mathrm{mL}$, et hydromorphone à $0,2 \mathrm{mg} / \mathrm{mL}$ + kétamine à $1,0 \mathrm{mg} / \mathrm{mL}$ ) dans une solution physiologique salée a été étudiée. Une partie de chaque préparation a été transvidée dans trois flacons de verre brun $(100 \mathrm{~mL})$, trois seringues de plastique $(50 \mathrm{~mL})$, et trois sacs i.v. $(50 \mathrm{~mL})$, qui ont ensuite été entreposés à la température ambiante $\left(25^{\circ} \mathrm{C}\right)$. Les propriétés physiques, notamment le $\mathrm{pH}$, la couleur et la présence de précipité, ont été évaluées quotidiennement. Trois échantillons de $1,5 \mathrm{~mL}$ ont été recueillis de chaque flacon, seringue et sac i.v. au départ, puis à 24,48 et 72 heures, et au jour 7. Les échantillons ont été analysés en triple à l'aide d'une épreuve validée par chromatographie liquide haute performance mesurant la stabilité. Les solutions étaient considérées stables si elles conservaient $90 \%$ de la concentration initiale de chaque médicament. Les échantillons des seringues et des sacs i.v. ont été soumis à des épreuves de stérilité standard par incubation pendant cinq jours dans un milieu de culture enrichi.

Résultats : Aucun changement notable du $\mathrm{pH}$ ou de la couleur ni précipité n'a été observé dans aucune des solutions. Toutes les préparations ont conservé plus de $90 \%$ de la concentration initiale de chaque médicament au jour 7 . Aucune croissance bactérienne n'a été observée dans aucun des échantillons testés.

Conclusions : Les mélanges d'hydromorphone et de kétamine sont demeurés stables pendant une période allant jusqu’à sept jours à une température de $25^{\circ} \mathrm{C}$, et les solutions sont demeurées stériles. Comme la stabilité seule ne peut garantir l'efficacité des médicaments, d'autres études cliniques sont recommandées afin d'évaluer les comportements pharmacocinétique et pharmacodynamique de ces préparations.

Mots clés : analgésie contrôlée par le patient, pédiatrie, stabilité, chromatographie liquide haute performance, hydromorphone, kétamine, douleur

[Traduction par l'éditeur] 


\section{INTRODUCTION}

$\mathrm{O}$ ral mucositis secondary to antineoplastic therapy is a challenging and severe pain problem in children. It typically requires parenteral opioid therapy, which is often administered by patient-controlled analgesia (PCA). The use of PCA for hydromorphone is standard practice at BC Children's Hospital. However, this therapy is often only marginally effective, and it is associated with a high incidence of opioidinduced side effects such as dysphoria, nausea, sedation, and pruritus. ${ }^{1-3}$ Ketamine, an established IV analgesic commonly used in pediatrics, has demonstrated efficacy in the treatment of pediatric acute pain and oncologic pain when combined with opioid therapy at subanesthetic doses. ${ }^{4.8}$

The goal of a planned observational pilot study at the authors' institution is to evaluate the feasibility, efficacy, and optimum ratio of a compounded mixture of hydromorphone and ketamine administered parenterally by PCA to children with mucositis who have inadequate analgesia with conventional hydromorphone by PCA. For the planned study, the drug combination will be prepared as hydromorphone $0.2 \mathrm{mg} / \mathrm{mL}$ with a variable dose of ketamine $(0.2,0.6$, or $1.0 \mathrm{mg} / \mathrm{mL}$ ) in $100 \mathrm{~mL}$ of $0.9 \%$ sodium chloride (normal saline [NS]). To the authors' knowledge, only one published study has evaluated the stability of the combination of hydromorphone and ketamine in NS. ${ }^{9}$ Although those investigators tested the stability of 4 hydromorphone-ketamine concentration combinations in glass test tubes, ${ }^{9}$ the concentrations of interest for use in the pediatric population are notably lower than those previously reported. Furthermore, the authors of the current study were not aware of any stability testing data for hydromorphone-ketamine solutions stored in plastic syringes or IV bags. Thus, the objective of the current study was to evaluate the stability of hydromorphone-ketamine solutions, at 3 different concentration combinations commonly used in pediatric practice, prepared in NS and stored for a period of up to 7 days at room temperature in 3 different types of container (glass bottles, plastic syringes, and IV bags).

\section{METHODS}

\section{Preparation of Hydromorphone-Ketamine Solutions}

Three independently prepared combinations of the 2 drugs were evaluated in each of 3 types of container. Stock solutions of the combination of hydromorphone (Sandoz Canada, Boucherville, Quebec; lot 137324, expiry January 2009) and ketamine (Sandoz Canada; lot 139132, expiry April 2009) were prepared from commercially available solutions, diluted in NS (Baxter Corporation, Toronto, Ontario; lot W7J24CO, expiry May 2009) to concentrations of 0.2 and $0.2 \mathrm{mg} / \mathrm{mL}, 0.2$ and $0.6 \mathrm{mg} / \mathrm{mL}$, and 0.2 and $1.0 \mathrm{mg} / \mathrm{mL}$, respectively. Portions of each combined solution were transferred to brown glass bottles (Richards Distribution, Richmond, British Columbia; 100-mL samples), plastic syringes (Becton Dickinson, Oakville, Ontario; lot 8058879; 50-mL samples), and IV bags (Baxter Corporation; lot W7L17CO; 50-mL samples). All solutions were kept in the dark at room temperature $\left(25^{\circ} \mathrm{C}\right)$.

The physical characteristics of the solutions were evaluated qualitatively at the time of preparation and on days $1,2,3$, and 7. As samples were collected for analysis during the study period, each solution was tested by the same individual (D.D.) and was visually examined for changes in colour (against white and black backgrounds) and for formation of precipitate. Three aliquots from each bottle, syringe, and IV bag were collected at each time point for determination of $\mathrm{pH}$. The $\mathrm{pH}$ meter was calibrated using commercially available standards at the beginning of each testing session. Immediately following the physical observations, $1.5-\mathrm{mL}$ samples were transferred to 2-mL polypropylene vials (VWR, Edmonton, Alberta; lot 108069978), which were immediately stored at $-85^{\circ} \mathrm{C}$ until analysis up to 6 weeks later by stability-indicating high-performance liquid chromatography (HPLC) with ultraviolet detection.

\section{Preparation of Stocks, Standards, and Standard Curve}

Stock solutions were prepared as follows: hydromorphone $2 \mathrm{mg} / \mathrm{mL}$ and ketamine $10 \mathrm{mg} / \mathrm{mL}$ were each diluted in NS to a concentration of $1 \mathrm{mg} / \mathrm{mL}$. The internal standard, naloxone $1 \mathrm{mg} / \mathrm{mL}$ (Sandoz Canada; lot 138390), was diluted in NS to a concentration of $0.5 \mathrm{mg} / \mathrm{mL}$. Standard solutions containing $0.05 \mathrm{mg} / \mathrm{mL}$ of the internal standard were prepared in NS with the following concentrations of hydromorphone and ketamine, respectively $(\mathrm{mg} / \mathrm{mL}): 0.26$ and $0.26,0.23$ and $0.23,0.20$ and $0.20,0.17$ and $0.17,0.10$ and $0.13,0.05$ and 0.09 , and 0.03 and 0.08. Each standard was passed through a $0.45-\mu \mathrm{m}$ microfilter to prevent injection of impurities onto the column.

A 7-point calibration curve was prepared with a blank (NS) at the beginning of each run, to ensure that there was no carry-over from one run to the next. The range of this calibration curve (from 0.26 and $0.26 \mathrm{mg} / \mathrm{mL}$ to 0.03 and $0.08 \mathrm{mg} / \mathrm{mL}$ hydromorphone and ketamine, respectively) encompassed the diluted test concentrations of hydromorphone $0.2 \mathrm{mg} / \mathrm{mL}$ with ketamine 0.2 to $1.0 \mathrm{mg} / \mathrm{mL}$. The calibration curve was generated by least-squares regression of the peak area ratio of hydromorphone-ketamine to naloxone (internal standard) and the concentration of each standard (hydromorphone-ketamine). Accuracy of the assay was calculated as the mean deviation between nominal and observed concentrations on 4 replicate samples (hydromorphone $0.15 \mathrm{mg} / \mathrm{mL}$ and ketamine $0.15 \mathrm{mg} / \mathrm{mL}$ ). The precision of the assay was evaluated by intraday and interday validation methods. Intraday variability was determined by running the following stock solutions in quadruplicate throughout a single 
day: hydromorphone and ketamine 0.25 and $0.25,0.15$ and $0.15,0.05$ and 0.09 , and 0.03 and $0.08 \mathrm{mg} / \mathrm{mL}$. Interday variability was determined by running the same concentrations (as in the testing for intraday variability) in quadruplicate daily for 4 days. The means, standard deviations, and coefficients of variation were then calculated. Acceptable limits for the coefficients of variation were defined a priori as less than $10 \%$.

\section{Preparation of Samples}

The hydromorphone-ketamine study samples were thawed, mixed by vortex mixer for $10 \mathrm{~s}$, and prepared as follows. For samples with nominal concentrations of hydromorphone $0.2 \mathrm{mg} / \mathrm{mL}$ and ketamine $0.2 \mathrm{mg} / \mathrm{mL}$, a $0.5-\mathrm{mL}$ aliquot was diluted with $0.1 \mathrm{~mL}$ naloxone (internal standard) and $0.4 \mathrm{~mL}$ NS. For samples with nominal concentrations of hydromorphone $0.2 \mathrm{mg} / \mathrm{mL}$ and ketamine $0.6 \mathrm{mg} / \mathrm{mL}$ or $1.0 \mathrm{mg} / \mathrm{mL}$, a $0.25-\mathrm{mL}$ aliquot was diluted with $0.1 \mathrm{~mL}$ naloxone and $0.650 \mathrm{~mL}$ NS. The final theoretical concentrations of hydromorphone and ketamine, respectively, after sample preparation were as follows $(\mathrm{mg} / \mathrm{mL}): 0.1$ and $0.1,0.05$ and $0.15,0.05$ and 0.25 . In addition, a quality control sample (hydromorphone $0.15 \mathrm{mg} / \mathrm{mL}$ and ketamine $0.15 \mathrm{mg} / \mathrm{mL}$ ) was added to each HPLC run. Each sample was passed through a $0.45-\mu \mathrm{m}$ microfilter before a $25-\mu \mathrm{L}$ sample was withdrawn and injected onto the column.

\section{HPLC Instrumentation}

The HPLC instrumentation (model 2690, Waters Alliance System, Waters Ltd, Mississauga, Ontario) consisted of a delivery pump, an automatic injector system equipped with a $200-\mu \mathrm{L}$ injector, an Atlantis dC18 $4.6 \times 150 \mathrm{~mm}$ column (Waters Ltd; lot 01293709613840), an Atlantis dC18 $3.9 \times 20$ mm guard column (Waters Ltd; lot 129371141), and an ultraviolet detector set at $203 \mathrm{~nm}$. The mobile phase was developed in the authors' laboratory and consisted of a gradient mixture of 11\%-52.5\%-90\%-11\% methanol (Fisher Scientific, Richmond, British Columbia; lot D0372) and $89 \%-47.5 \%-10 \%-89 \%$ of $5 \mathrm{mmol} / \mathrm{L}$ potassium phosphate buffer (Sigma-Aldrich Canada Ltd, Oakville, Ontario; lot $125 \mathrm{~K} 0169)$ with $10 \mathrm{mmol} / \mathrm{L}$ ethylenediaminetetra-acetic acid (Sigma-Aldrich Canada Ltd; lot $11 \mathrm{~K} 0315$ ) at pH 3.15 over a period of $10 \mathrm{~min}$. All solvents were HPLC-grade and were filtered before use. The flow rate was set at $1.2-1.5 \mathrm{~mL} / \mathrm{min}$.

\section{Degradation of Hydromorphone and Ketamine}

A mixture of hydromorphone $0.25 \mathrm{mg} / \mathrm{mL}$ and ketamine $1 \mathrm{mg} / \mathrm{mL}$ was prepared from $1 \mathrm{mg} / \mathrm{mL}$ stock solutions of each drug. The $\mathrm{pH}$ was adjusted to 9.0 with sodium hydroxide $2 \mathrm{~N}$, and the sample was incubated for $18 \mathrm{~h}$ at $90^{\circ} \mathrm{C}$. The sample was cooled to room temperature, the $\mathrm{pH}$ was readjusted to 4.1 with hydrochloric acid $1 \mathrm{~N}$, and the sample was boiled for $10 \mathrm{~min}$. The sample was then adjusted with NS to final concentrations of hydromorphone $0.05 \mathrm{mg} / \mathrm{mL}$ and ketamine $0.20 \mathrm{mg} / \mathrm{mL}$, filtered, and injected onto the column. The chromatogram obtained for the degraded preparation was compared with a chromatogram obtained from the standard curve to determine any changes in concentration, retention time, and peak shape.

\section{Sterility of Hydromorphone and Ketamine Mixture}

A 5-mL sample of each combined solution of hydromorphone and ketamine was drawn from each syringe and IV bag on day 0 (immediately after preparation of the solutions) and was incubated in $10 \mathrm{~mL}$ of thioglycolate-enriched culture broth to test for the presence of both anaerobic and aerobic bacteria. The mixtures were placed in an ambient air incubator at $35^{\circ} \mathrm{C}$ for 5 days. Absence of bacterial growth after 5 days under these conditions was considered to indicate sterility.

\section{Statistical Analysis}

Means, standard deviations, and coefficients of variation were calculated for samples analyzed in triplicate or quadruplicate. For each study day, the percentage of the initial hydromorphone and ketamine concentrations remaining was calculated for each sample. The percentage of hydromorphone and ketamine remaining on day 7 was calculated from the concentration on day 7 , as determined by linear regression and the concentration observed on day 0 , according to the following formula: (concentration on day $7 /$ concentration on day 0 ) $\times 100 \%$. The $95 \%$ confidence interval (CI) of the amount remaining on the last study day was calculated from the lower limit of the $95 \%$ CI of the slope of the curve relating concentration to time, determined by linear regression, via computer analysis, according to the following formula: lower limit of the 95\% CI of (concentration on day $7 /$ concentration on day 0 ) $\times 100 \%$. Stability was defined as maintenance of at least $90 \%$ of the initial hydromorphone and ketamine concentrations.

\section{RESULTS}

For the standard curve generated as described above, regression analysis of the peak area ratio of hydromorphone and ketamine (standards) to internal standard versus concentration demonstrated linearity over the working range of the standard concentrations, with coefficients of determination $\left(r^{2}\right)$ greater than $0.990(n=4)$. The mean deviation between the nominal and observed concentrations was below $1.5 \%$ (i.e., accuracy of $98.5 \%)$. The intraday $(n=4)$ and interday $(n=4)$ coefficients of variation for the 4 different concentrations of standards were within acceptable limits (i.e., < 10\%): $2.3 \%$ and 3.1\%, respectively, for hydromorphone and $0.70 \%$ and $3.40 \%$, 
respectively, for ketamine in the combined solution with $0.25 \mathrm{mg} / \mathrm{mL}$ of each drug; $1.99 \%$ and $2.56 \%$, respectively, for hydromorphone and $2.23 \%$ and $3.09 \%$, respectively, for ketamine in the combined solution with $0.15 \mathrm{mg} / \mathrm{mL}$ of each drug; $1.29 \%$ and $3.80 \%$, respectively, for hydromorphone and $1.39 \%$ and $3.02 \%$, respectively, for ketamine in the solution with 0.05 and $0.09 \mathrm{mg} / \mathrm{mL}$ of the respective drugs; and $0.18 \%$ and $3.63 \%$ respectively, for hydromorphone and $0.21 \%$ and $1.57 \%$, respectively, for ketamine in the solution with 0.03 and $0.08 \mathrm{mg} / \mathrm{mL}$ of the respective drugs.

The retention times were, on average, $3.87 \mathrm{~min}$ for hydromorphone, $5.86 \mathrm{~min}$ for ketamine, and $7.60 \mathrm{~min}$ for the internal standard, naloxone. When the hydromorphone-ketamine solution was subjected to degradation, the hydromorphone peak completely disappeared and the ketamine peak was reduced by $40 \%$ relative to that of the standard curve. No interfering peaks were detected (Figure 1). Thus, the HPLC method was deemed capable of indicating stability.

Each clear solution had a neutral smell. No notable changes in physical appearance, odour, or colour of the solutions were observed over the 7-day storage period. No significant fluctuations in $\mathrm{pH}$ were observed (Table 1).

The HPLC analysis showed that, at room temperature, all 9 mixtures maintained between $90 \%$ and $110 \%$ of their initial concentrations on every study day (Tables 2 to 4). Furthermore, more than $95 \%$ of the initial hydromorphone and ketamine concentrations remained on day 7 , according to linear regression analysis of the concentration-time data. As well, after 5 days of incubation, none of the samples demonstrated any bacterial growth.

\section{DISCUSSION}

To the authors' knowledge, the only published stability analysis of hydromorphone and ketamine in normal saline was conducted by Walker and others ${ }^{9}$ in 2001. In their sophisticated 2-part study (24-h physical compatibility of 12 concentration combinations in the first part of the study and 24-day compatibility and chemical stability of 4 concentration combinations in the second part), the investigators determined that concentration combinations of 1.0 and $0.5 \mathrm{mg} / \mathrm{mL}, 20.0$ and $0.5 \mathrm{mg} / \mathrm{mL}, 1.0$ and $20.0 \mathrm{mg} / \mathrm{mL}$, and 20.0 and $20.0 \mathrm{mg} / \mathrm{mL}$ (hydromorphone and ketamine, respectively) were stable when stored in glass at $4^{\circ} \mathrm{C}$ or $23^{\circ} \mathrm{C}$ for 24 days. ${ }^{?}$

Although PCA with hydromorphone-ketamine may hold promise for children with mucositis who have inadequate analgesia with conventional hydromorphone PCA, no stability data on hydromorphone-ketamine solutions specifically for

\section{Standard HM / K $(0.10 / 0.13 \mathrm{mg} / \mathrm{mL})$}

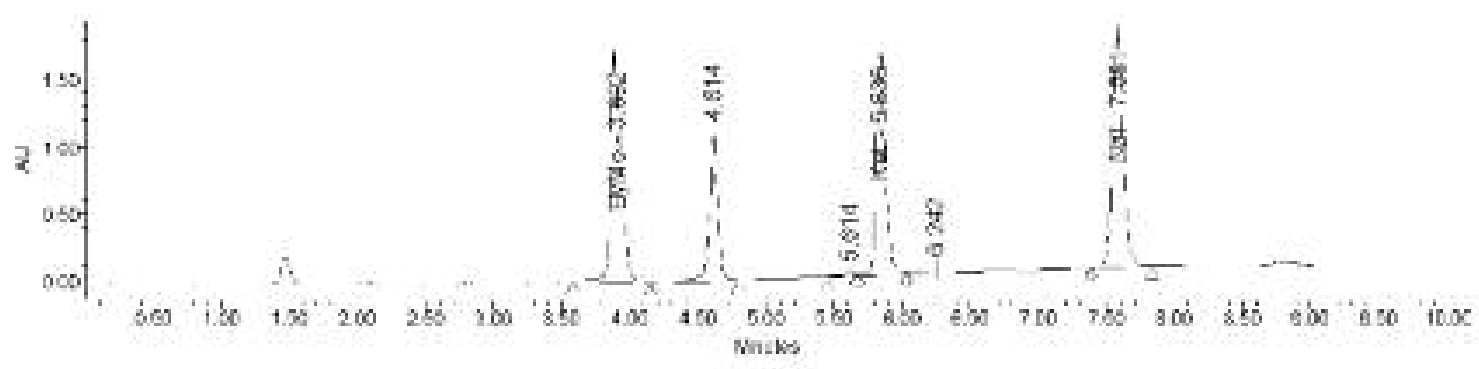

\section{Degradation sample}

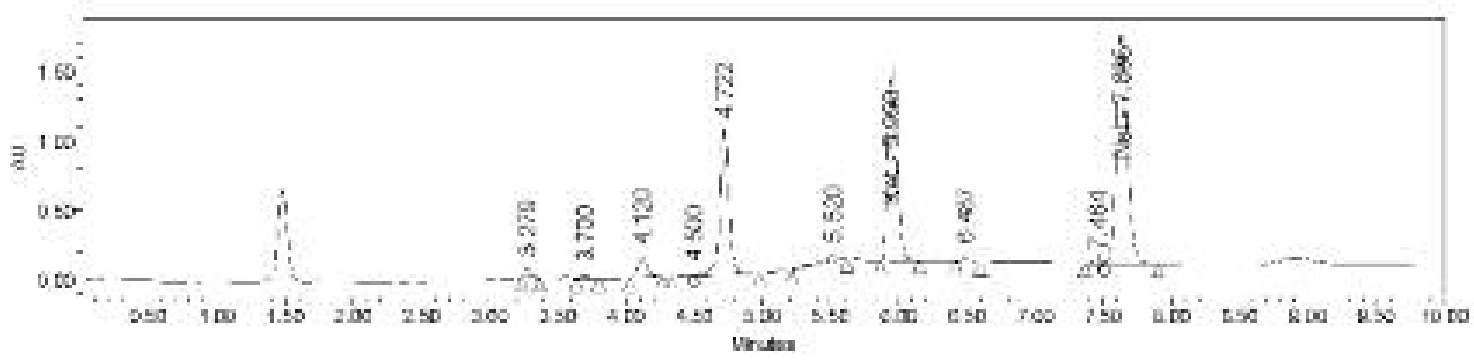

Figure 1. Top: Peaks for undegraded samples of hydromorphone at $3.89 \mathrm{~min}$, ketamine at $5.84 \mathrm{~min}$, and the internal standard (naloxone) at $7.58 \mathrm{~min}$. Bottom: Degraded preparation shows disappearance of the hydromorphone peak, a $40 \%$ reduction in the ketamine peak, and no interfering peaks. HyMO = hydromorphone, Ket $=$ ketamine, Nal = naloxone, $\mathrm{AU}=$ absorbance units. 
Table 1. Mean pH of Mixtures of Hydromorphone and Ketamine After 7 Days of Storage at $25^{\circ} \mathrm{C}$

\begin{tabular}{lccc} 
& \multicolumn{2}{c}{ Drug Concentration $(\mathbf{m g} / \mathbf{m L})$} & \\
\cline { 2 - 3 } Container & Hydromorphone & Ketamine & pH (Mean \pm SD) \\
\hline Glass bottles & 0.20 & 0.20 & $4.682 \pm 0.096$ \\
& 0.20 & 0.60 & $4.768 \pm 0.017$ \\
\hline Syringes & 0.20 & 1.00 & $4.764 \pm 0.011$ \\
& 0.20 & 0.20 & $4.486 \pm 0.053$ \\
& 0.20 & 0.60 & $4.596 \pm 0.018$ \\
PVC bags & 0.20 & 1.00 & $4.546 \pm 0.028$ \\
& 0.20 & 0.20 & $4.542 \pm 0.037$ \\
& 0.20 & 0.60 & $4.596 \pm 0.017$ \\
SD = standard deviation, & 0.20 & 1.00 & $4.612 \pm 0.027$ \\
\hline
\end{tabular}

Table 2. Percentage of Initial Concentration of Hydromorphine $(0.2 \mathrm{mg} / \mathrm{mL})$ and Ketamine $(0.2 \mathrm{mg} / \mathrm{mL})$ Remaining after 7 Days of Storage at $25^{\circ} \mathrm{C}$ in Glass Bottles, Plastic Syringes, or IV Bags

\begin{tabular}{|c|c|c|c|c|c|c|}
\hline \multirow[b]{2}{*}{ Variable } & \multicolumn{2}{|c|}{ Glass Bottles } & \multicolumn{2}{|c|}{ Plastic Syringes } & \multicolumn{2}{|c|}{ IV Bags } \\
\hline & Hydromorphone & Ketamine & Hydromorphone & Ketamine & Hydromorphone & Ketamine \\
\hline $\begin{array}{l}\text { Initial } \\
\text { concentration } \\
(\mathrm{mg} / \mathrm{mL})^{\star}\end{array}$ & $0.183 \pm 0.001$ & $0.209 \pm 0.001$ & $0.198 \pm 0.003$ & $0.196 \pm 0.008$ & $0.203 \pm 0.001$ & $0.215 \pm 0.002$ \\
\hline \multicolumn{7}{|l|}{ Study day } \\
\hline 1 & 100.55 & 100.96 & 101.01 & 96.43 & 97.04 & 97.67 \\
\hline 2 & 102.19 & 103.35 & 95.45 & 108.67 & 100.00 & 105.12 \\
\hline 3 & 101.64 & 99.52 & 101.52 & 102.55 & 95.57 & 96.28 \\
\hline 7 & 101.09 & 104.78 & 93.94 & 94.39 & 100.49 & 91.63 \\
\hline $\begin{array}{l}\text { Estimated \% } \\
\text { remaining on } \\
\text { day } 7 \dagger\end{array}$ & 100.80 & 100.18 & 100.61 & 102.47 & 98.16 & 101.49 \\
\hline $\begin{array}{l}\text { Lower } 95 \% \mathrm{Cl} \\
\text { for } \% \text { remaining } \neq\end{array}$ & 98.85 & 96.34 & 94.40 & 90.00 & 93.01 & 92.99 \\
\hline \multicolumn{7}{|c|}{$\begin{array}{l}\mathrm{Cl}=\text { confidence interval. } \\
* \text { Nominal initial concentrations } 0.2 \mathrm{mg} / \mathrm{mL} \text { for both hydromorphone and ketamine. } \\
+ \text { +Calculated from concentration on day } 7 \text { as determined by linear regression and concentration observed on day } 0 \text {, according to the } \\
\text { following formula: concentration on day } 7 \text { divided by concentration on day } 0 \times 100 \text {. } \\
\neq \text { Calculated from lower limit of } 95 \% \mathrm{Cl} \text { of the slope of the curve relating concentration to time, determined by linear regression, } \\
\text { according to the following formula: lower limit of } 95 \% \mathrm{Cl} \text { of (concentration on day } 7 \text { divided by concentration on day } 0 \text { ) } \times 100 \text {. }\end{array}$} \\
\hline
\end{tabular}

pediatric use were available. In addition, no data were found regarding the stability of these solutions when stored in plastic syringes or IV bags. Thus, before such mixtures were administered to patients (as in the proposed study described above), the stability of 3 different mixtures of hydromorphone and ketamine $(0.2$ and $0.2 \mathrm{mg} / \mathrm{mL}, 0.2$ and $0.6 \mathrm{mg} / \mathrm{mL}$, and 0.2 and $1.0 \mathrm{mg} / \mathrm{mL}$, respectively), prepared in NS, was assessed for a period of up to 7 days, with storage at room temperature in glass bottles, plastic syringes, or IV bags.

In the daily analysis of samples, there were no notable changes in $\mathrm{pH}$ or colour in any of the solutions stored in glass bottles, plastic syringes, or IV bags at $25^{\circ} \mathrm{C}$ for 7 days. All formulations of hydromorphone-ketamine maintained at least $90 \%$ of their initial concentration.

The absence of bacterial growth in all incubated samples demonstrated that sterility of these preparations was maintained under the study conditions. However, there is a potential risk for contamination or the potential for bacterial growth in a contaminated sample if it were stored at $25^{\circ} \mathrm{C}$. Although Canadian pharmacies are not subject to the standards of USP (United States Pharmacopeia) chapter $<797>,{ }^{10}$ it remains the best current document integrating information about degradation rate (expiry dates) and sterility. It specifies that storage at room temperature for low-risk compounding should not exceed 48 hours. ${ }^{10}$ Given that sterility can change according to site, equipment, operator, and procedures used, the following cautions are suggested: (i) the finding of no growth after storage for 5 days at $25^{\circ} \mathrm{C}$ in this study does not mean that all combined solutions of hydromorphone and ketamine will be sterile, and (ii) before using an expiry date of 7 days for any solution stored at room temperature, consideration should be given to the contamination rate within the institution's IV additive program. 
Table 3. Percentage of Initial Concentration of Hydromorphine $(0.2 \mathrm{mg} / \mathrm{mL})$ and Ketamine $(0.6 \mathrm{mg} / \mathrm{mL})$ Remaining after 7 Days of Storage at $25^{\circ} \mathrm{C}$ in Glass Bottles, Plastic Syringes, or IV Bags

\begin{tabular}{|c|c|c|c|c|c|c|}
\hline \multirow[b]{2}{*}{ Variable } & \multicolumn{2}{|c|}{ Glass Bottles } & \multicolumn{2}{|c|}{ Plastic Syringes } & \multicolumn{2}{|c|}{ IV Bags } \\
\hline & Hydromorphone & Ketamine & Hydromorphone & Ketamine & Hydromorphone & Ketamine \\
\hline $\begin{array}{l}\text { Initial } \\
\text { concentration } \\
(\mathrm{mg} / \mathrm{mL})^{\star}\end{array}$ & $0.186 \pm 0.007$ & $0.602 \pm 0.008$ & $0.179 \pm 0.155$ & $0.543 \pm 0.023$ & $0.164 \pm 0.012$ & $0.543 \pm 0.009$ \\
\hline \multicolumn{7}{|l|}{ Study day } \\
\hline 1 & 101.08 & 100.50 & 96.21 & 93.37 & 97.56 & 99.82 \\
\hline 2 & 94.09 & 99.17 & 96.65 & 101.84 & 109.15 & 101.29 \\
\hline 3 & 99.46 & 103.65 & 93.85 & 98.34 & 102.44 & 95.58 \\
\hline 7 & 104.84 & 104.65 & 90.50 & 95.95 & 91.46 & 106.08 \\
\hline $\begin{array}{l}\text { Estimated \% } \\
\text { remaining on } \\
\text { day } 7 \dagger\end{array}$ & 97.86 & 99.67 & 98.66 & 98.70 & 103.52 & 98.37 \\
\hline $\begin{array}{l}\text { Lower } 95 \% \mathrm{Cl} \\
\text { for } \% \text { remaining }\end{array}$ & 90.05 & 96.44 & 95.98 & 90.91 & 90.38 & 91.12 \\
\hline $\begin{array}{l}\mathrm{Cl}=\text { confidence in } \\
\star \text { Nominal initial } \mathrm{cc} \\
+ \text { Calculated from } \\
\text { following formula } \\
\neq \text { Calculated from } \\
\text { according to the } f\end{array}$ & $\begin{array}{l}\text { terval. } \\
\text { oncentrations: hyo } \\
\text { concentration on } \\
\text { : concentration on } \\
\text { lower limit of } 95 \% \\
\text { following formula: }\end{array}$ & $\begin{array}{l}\text { orphone } 0.2 \\
7 \text { as determi } \\
7 \text { divided b) } \\
\text { of the slope }\end{array}$ & $\begin{array}{l}\mathrm{mL} \text {, ketamine } 0.6 \\
\text { by linear regressic } \\
\text { ccentration on da } \\
\text { ne curve relating }\end{array}$ & $\begin{array}{l}\mathrm{g} / \mathrm{mL} \text {. } \\
\text { and concentrat } \\
\text { x } 100 \text {. } \\
\text { centration to } t\end{array}$ & $\begin{array}{l}\text { observed on day } \\
\text { determined by li } \\
\text { concentration or }\end{array}$ & $\begin{array}{l}\text { according to the } \\
\text { ar regression, } \\
\text { ay } 0) \times 100 \text {. }\end{array}$ \\
\hline
\end{tabular}

Table 4. Percentage of Initial Concentration of Hydromorphine $(0.2 \mathrm{mg} / \mathrm{mL})$ and Ketamine $(1.0 \mathrm{mg} / \mathrm{mL})$ Remaining after 7 Days of Storage at $25^{\circ} \mathrm{C}$ in Glass Bottles, Plastic Syringes, or IV Bags

\begin{tabular}{|c|c|c|c|c|c|c|}
\hline \multirow[b]{2}{*}{ Variable } & \multicolumn{2}{|c|}{ Glass Bottles } & \multicolumn{2}{|c|}{ Plastic Syringes } & \multicolumn{2}{|c|}{ IV Bags } \\
\hline & Hydromorphone & Ketamine & Hydromorphone & Ketamine & Hydromorphone & Ketamine \\
\hline $\begin{array}{l}\text { Initial } \\
\text { concentration } \\
(\mathrm{mg} / \mathrm{mL})^{\star}\end{array}$ & $0.184 \pm 0.066$ & $1.014 \pm 0.019$ & $0.181 \pm 0.001$ & $0.957 \pm 0.001$ & $0.172 \pm 0.005$ & $0.911 \pm 0.002$ \\
\hline \multicolumn{7}{|l|}{ Study day } \\
\hline 1 & 100.00 & 96.84 & 92.82 & 97.60 & 103.49 & 101.87 \\
\hline 2 & 100.00 & 91.42 & 102.21 & 97.91 & 110.05 & 100.11 \\
\hline 3 & 101.63 & 92.70 & 100.55 & 98.12 & 100.58 & 97.59 \\
\hline 7 & 103.26 & 99.31 & 93.92 & 100.42 & 92.44 & 105.38 \\
\hline $\begin{array}{l}\text { Estimated \% } \\
\text { remaining on } \\
\text { day } 7 \dagger\end{array}$ & 99.64 & 95.68 & 99.36 & 98.26 & 105.29 & 99.24 \\
\hline $\begin{array}{l}\text { Lower } 95 \% \mathrm{Cl} \\
\text { for } \% \text { remaining }\end{array}$ & 98.56 & 86.41 & 89.82 & 95.44 & 93.60 & 93.82 \\
\hline \multicolumn{7}{|c|}{$\begin{array}{l}\mathrm{Cl}=\text { confidence interval. } \\
* \text { Nominal initial concentrations: hydromorphone } 0.2 \mathrm{mg} / \mathrm{mL} \text {, ketamine } 1.0 \mathrm{mg} / \mathrm{mL} \text {. } \\
+ \text { Calculated from concentration on day } 7 \text { as determined by linear regression and concentration observed on day } 0 \text {, according to the } \\
\text { following formula: concentration on day } 7 \text { divided by concentration on day } 0 \times 100 \text {. } \\
\neq \text { Calculated from lower limit of } 95 \% \mathrm{Cl} \text { of the slope of the curve relating concentration to time, determined by linear regression, } \\
\text { according to the following formula: lower limit of } 95 \% \mathrm{Cl} \text { of (concentration on day } 7 \text { divided by concentration on day } 0) \times 100 \text {. }\end{array}$} \\
\hline
\end{tabular}

A limitation of this study design relates to the freezing of samples at $-85^{\circ} \mathrm{C}$ until the time of batch analysis. It was assumed that neither hydromorphone nor ketamine would degrade at this low temperature and that no volume losses would occur because of freeze-drying during storage over a 6-week period. As well, errors due to serial analysis were assumed to have been greater than errors occurring with batch analysis. In vitro determination of stability of a preparation does not automatically guarantee that pharmacokinetics and pharmacodynamics will be unchanged in vivo, and follow-up pharmacokinetic and pharmacodynamic studies should be performed.

\section{References}

1. Dunbar PJ, Chapman CR, Buckley FP, Gavrin JR. Clinical analgesic equivalence for morphine and hydromorphone with prolonged PCA. Pain 1996;68(2-3):265-270

2. Collins JJ, Geake J, Grier HE, Houck CS, Thaler HT, Weinstein HJ, et al. Patient-controlled analgesia for mucositis pain in children: a threeperiod crossover study comparing morphine and hydromorphone. $J$ Pediatr 1996;129(5):722-728. 
3. Dunbar PJ, Buckley P, Gavrin JR, Sanders JE, Chapman CR. Use of patient-controlled analgesia for pain control for children receiving bone marrow transplant. J Pain Symptom Manage 1995;10(8):604-611.

4. Evans D, Turnham L, Barbour K, Kobe J, Wilson L, Vandebeek C, et al. Intravenous ketamine sedation for painful oncology procedures. Paediatr Anaesth 2005;15(2):131-138.

5. Roback MG, Wathen JE, Bajaj L, Bothner JP. Adverse events associated with procedural sedation and analgesia in a pediatric emergency department: a comparison of common parenteral drugs. Acad Emerg Med 2005;12(6):508-513.

6. Subramaniam K, Subramaniam B, Steinbrook RA. Ketamine as adjuvant analgesic to opioids: a quantitative and qualitative systematic review. Anesth Analg 2004;99(2):482-495.

7. Vandermeulen E. Systemic analgesia and co-analgesia. Acta Anaesthesiol Belg 2006;57(2):113-120.

8. Kronenberg RH. Ketamine as an analgesic: parenteral, oral, rectal, subcutaneous, transdermal and intranasal administration. $J$ Pain Palliat Care Pharmacother 2002;16(3):27-35.

9. Walker SE, Law S, DeAngelis C. Stability and compatibility of hydromorphone and ketamine in normal saline. Can J Hosp Pharm 2001;54(3):191-199.

10. Kastango ES, Bradshaw BD. USP chapter 797: establishing a practice standard for compounding sterile preparations in pharmacy. Am J Health Syst Pharm 2004;61(18):1928-1938.
Mary H H Ensom, PharmD, FASHP, FCCP, FCSHP, FCAHS, is Professor and Director, Doctor of Pharmacy Program, Faculty of Pharmaceutical Sciences, and Distinguished University Scholar, The University of British Columbia; and Clinical Pharmacy Specialist, Department of Pharmacy, Children's and Women's Health Centre of British Columbia, Vancouver, British Columbia. She is also the Editor of CJHP.

Diane Decarie, BSc, is Research Consultant, Department of Pharmacy, Children's and Women's Health Centre of British Columbia, Vancouver British Columbia.

Karen Leung, BScPhm, is the Pharmacy Research Facilitator Department of Pharmacy, Children's and Women's Health Centre of British Columbia, Vancouver, British Columbia.

Carolyne Montgomery, MD, FRCPC, is Clinical Professor and Pediatric Anesthesia Fellowship Director, Department of Anesthesiology, Pharmacology and Therapeutics, University of British Columbia, and Pediatric Anesthesiology and Pain Management, BC Children's Hospital, Vancouver, British Columbia.

\section{Address correspondence to:}

Dr Mary H H Ensom

Pharmacy Department (OB7)

Children's and Women's Health Centre of British Columbia

4480 Oak Street

Vancouver BC

V6H 3V4

e-mail: ensom@interchange.ubc.ca

\section{Acknowledgements}

We thank Lillian Ting for reviewing the manuscript before submission and Dr Eddie Kwan for assisting with the sterility testing. The study was supported by the BC Children's Hospital Foundation Telethon Awards. 